\title{
Context of Trade Canal and Industrial Heritage in Liepaja
}

\author{
Dace Ržepicka, Aija Ziemeḷniece \\ Department of Landscape Architecture and Planning, Faculty of Environment and Civil Engineering, Latvia \\ University of Agriculture. Address: Rīgas iela 22, Jelgava, LV-3004, Latvia.dace.rzepicka@inbox.lv; aija@k- \\ projekts.lv
}

\begin{abstract}
Today, the historic Trade Canal in Liepajja begins to rapidly recover the character of an outdoor public space of an aesthetically high quality. After the two devastating world wars, the industrial heritage has only remained along the left bank of the canal, requiring a very gentle treatment of the cultural and historical values. The new industrial building that has occupied both banks of the canal from the 60s-70s of the 20th century strongly contrast with the historic building scale, materials, and the application of the architecturally compositional elements. The modern construction technologies can build powerful allegoric comparisons in the language of the architectural form building. This applies both to the wide glazing of the building facade, the curved facade shapes, the structure of the covering material, the green areas, etc.. The revival of the left bank of the canal is a good challenge to also recover the historic urban space on the right bank of the canal or at the side of Jaunliepajja. Currently, this waterfront of the canal, which is untouched by the war, consists of a circumferentially dense production area.
\end{abstract}

Keywords: urban structure, language of the form creation, urban scale and space, industrial heritage.

\section{INTRODUCTION}

On the canvas of the urban constructed space in Liepāja, the Trade Canal plays an essential role. Around the second half of the $19^{\text {th }}$ century, the creation of an intensive production area was commenced. The building character of the northern side of the canal is readable in 1871 in the design drawn by P. M. Bertschy (Krastiņš, 2015). The area was also surrounded by a railway line located between the canal and the area of the cemetery on the right bank of the canal and on the left bank of the warehouse building. The railway and the sea route were the only ones which in the second half of the $19^{\text {th }}$ century provided the import of raw materials and export of the finished products. The author of several buildings of the industrial and residential building in Jaunliepāja is Bertschy himself and in many places, the buildings are built from the red brick.

The factory was one of the most vibrant visual indicators of the urban economic development and prosperity indicators of the first half of the $19^{\text {th }}$ and the $20^{\text {th }}$ centuries. Today, the historic factories where the production is stopped, as well as their equipment and products serve as an evidence that may help to understand the life and culture of the past. In the early $21^{\text {st }}$ century, the industrial heritage in many parts of Europe has become a recognized and protected part of the cultural heritage.

Industrial facilities of a high architectural quality, located in city centers in Europe, are mostly converted into public facilities. It is important not only to transform and regenerate but also to save the material evidence of the city's economic and cultural growth in the form of industrial facilities. (figure 3). The provision of this aim will depend not only on the economic development in the early $21^{\text {st }}$ century, but also of the city's political and economic power and the desire to recognize and appreciate the city's most important historical phases of growth (Anteniške, 2002).

The preservation of the industrial landscape space in many European countries is already dealt with in the framework of urban planning and in designing special programs for the heritage protection. For instance, already in 1976 in Norcheping the decision of the City Council included to:

- Maintain the characteristic features of the industrial landscape;

- Open areas with public access and build sidewalks, public places, and public buildings within the boundaries of these zones;

- Maintain the water flow and increase open water sites;

- Build a zone in an attractive and significant part of the city.

Norcheping is described by a situation where the factories and plants on the banks of the Strommen river together with the waterfalls, dams, and reflections in the water have created a unique urban environment, which is a composition comparable to the landscape space of the Trade Canal in Liepaja 
where the industrial coloring stands out in the vibrant environment of the natural elements.

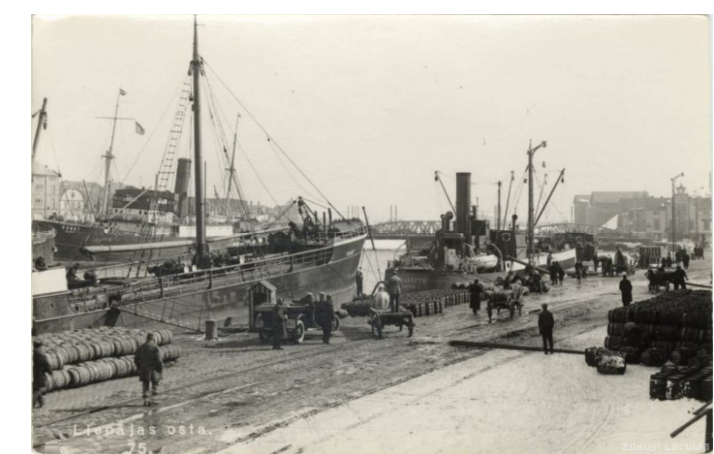

Fig. 1. Fishing boats on the left bank of the canal.

30 s of the $20^{\text {th }}$ century. (Museum of Liepaja)

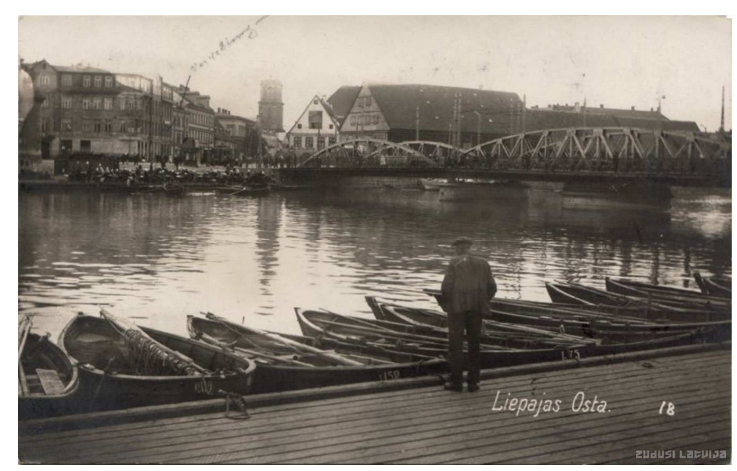

Fig.2. Boats on the right bank of the canal.

$30 \mathrm{~s}$ of the $20^{\text {th }}$ century. (Museum of Liepaja)

At the same time, the decision of 1976 provided, "... to create by the river such an industrial landscape that could become a significant component of the environment" (Bredin, 2002). The postindustrial use of the factory environment in Finland dates back to the early 90 s of the $20^{\text {th }}$ century. All activities take place knowing the neighborhood's history, and the industrial heritage is also apprehended, which is an essential component of the cultural heritage (Sivula,2002).

Why is the industrial heritage so important (for science, history of science)? Because it embodies, materializes the scientific advances, technological advances. Sometimes the empirical, elsewhere - the theoretical, analytical, knowledge comes into the human, nation's, society's, public, and everyday life, cities and the state history. In a sense, this heritage is a live history of science, condensed in cars, buildings, and other facilities (Stradiņš,2002). The industrial heritage is an important part of the history of the society, an element of a growing city. And nothing is over yet - the industrial development is still keeping pace together with the development of the information society. The industrial heritage is not only real estate. It also includes a tremendous progress in the development of transport, communications, connecting people, lifestyle, traditions, the lost era, and the goodwill spirit (Wennerholm,2002).

The technical monuments or the industrial heritage is telling a story not only of the level of the public material welfare, types of mutual communication but also of the human spiritual perception, emotions, feelings, ideals, and the criteria of values. Every scientific and technical discovery affects individuals and the society as a whole, its economic, social, and psychological content. The human intellect produces a myriad of novelties that change the life of the society, creating around itself a field of new power, operation, and understanding. Therefore, the industrial heritage is considered to be a unique witness of the humanity's spiritual, creative, and material history (Lastovecka, 2002).

\section{MATERIALS AND METHODS}

A vivid example of the above is the dense position in the areas of the historic production and Liepāja, including the port along the right side of the Trade Canal (figure 1,2). Part of the area actively functions and in addressing the infrastructure of tourism attraction, it has to be considered. This is especially true for the public access to the building of the end of the $19^{\text {th }}$ century at $O$. Kalpaka street where architecturally and artistically brilliant works of architect Bertschy are located. The density of the historic building of the two waterfronts of the canal is in a dramatical contrast. It is based on the devastation of the Second World War as alongside with burning down of the building on the left bank until Rožu Square free areas were created. In the postwar years, they were filled up with the scale and structure alien to the historical urban environment. Only in the last twenty years, a major reconstruction of the old levee was commenced which allowed to solve the issues of the recently created promenade zone, the new concert hall, and the high-rise residential building built in the Soviet times which held the scale in a dramatical contrast with the proportions of the historical building of the city and the language of the form creation.

Today, any planning of the urban space and development are increasingly targeted to arrange it from the economic, functional, and architectural point of view. (Brinkis,2008). It is based on the development of production processes, improving the living conditions of the population, rational use of natural resources and protection. One of the key aspects is the awareness and protection of the cultural and historical heritage, promoting the development of tourism infrastructure and creating the recreation area, allocating modern functions, reviving the abandoned areas of factories as the commerce and trade, business centers, the sports, health care, and hotel sector or the exhibition and arts complex where it is likely that the functions will be fused.

An essential role in this context is played by the modern scientific and technical progress, which 
makes an avant-garde contribution to the technological processes of the design of the urban space and the construction. In the planning model of Liepāja, it is clearly readable that in creating a single system of the space development or a canvas, its detail elements are closely related to individual, small architectural, and spatial issues.

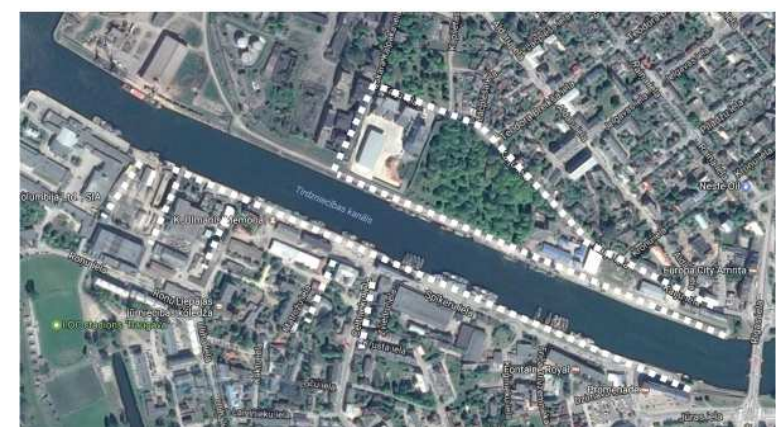

Fig.3 Exposure points of Trade canal of Liepaja (modified of authors)

The research includes several criteria that have influenced the transformation processes of the landscape space of the Trade Canal from the 70s of the $19^{\text {th }}$ century up to the present day. This includes the time frame when the city planning was started by architect Paul Max Bertschy. Liepāja is a relatively new city as the city rights were granted to it in 1625 by Frederick, Duke of Courland (Krastiņš, 2015)

At the end of the $19^{\text {th }}$ century, Liepāja - a nonfreezing port city of the Courland governorate was already established as a powerful industrial center with a cast iron and steel foundry, oil factory, aniline color factory, steam mills, cork factory, linoleum factory, brewery, etc. (Krastiņš,2015).

It allowed solving issues of the new promenade zone, the new concert hall, and the high-rise residential building built in the Soviet times which held the scale in dramatic contrast with the proportions of the historical building of the city and the language of form creation.

The newly built railway and the historic sea route were the only ones which in the second half of the $19^{\text {th }}$ century provided import of raw materials and export of finished products. The rapid boom of the city's infrastructure, the subsequent devastation of both wars, the postwar totalitarianism permanently deprived the city of architecturally excellent buildings, and the city skyline along the waterfront of the canal. Layering of the extremely complex structure of the building along the waterfront of the canal area serves as a vivid page of our history where the economic, industrial and cultural phases are readable.

The research aims to examine the context of the waterfront of the canal, the green areas, and the form creation of the architecture of the industrial heritage of the cultural landscape of the Trade Canal.

The assignment of the research is to assess the nature of the two waterfronts of the canal which consist of several sections of the waterfront of the canal areas, their different building scale, density and the spatial volume of the green structure.

Two main methodological approaches are used in the research:

- The comparative method - the study of the development of the area based on the study of the historical and the current situation, and analysis of the processes in certain periods of time.

- The complex method, by synthesizing the scenic, cultural environment, economic, and architecturally spatial aspects.

\section{RESULTS AND DISCUSSIONS}

Termination of production in the historical industrial buildings and the lack of regular new users or investors are the reasons why the degradation and devastation of industrial monuments or even destruction accelerate. In the areas of a developed industrial heritage, the industrial landscape is a site that symbolizes knowledge and culture (Sivula,2002).

In urban planning, separate building nodes or centers as architecturally spatial landmarks are functionally arranged with a particular architectural and artistically compositional value. The groups of settlements are not a sum of mechanical components but an architecturally and artistically synthesized quality. In the urban space perception, separate static points of sight are not so crucial as a visual image perceived in movement. The analysis of the silhouettes of the historic sites shows that the verticals always bring out the main node points of the architectural space. This is attributable to the landscape space of the industrial heritage before the flow of the Trade Canal into the sea, where the vertical accents of its left bank highlight two dominants - the wind rotor, symbolizing the beginning of the $21^{\text {st }}$ century, and the nearby sea lighthouse, marking the start of the $20^{\text {th }}$ century. Both have a symbolic importance in the history of Liepāja and in the context with the left bank pedestrian promenade it is playing a compositionally strong role in the perception of the landscape space of the canal. The expression of the canal is increased by the form creation of the adjacent industrial building and coloring, attributable to the clay brick masonry. The perception of the landscape space is best readable: 1) In the near sight lines, mainly perceived by pedestrians, users of certain areas; 2) In the long distance sight lines, which allows reading the silhouette of certain areas.

The canal serves as the city's "blue" backbone which connects the left bank streets and the narrow driveways with tree lines and individual groups or lines of shrubs. As previously mentioned, the city was burnt down from the old levee to Rose Square. Especially, it is noticeable today where the building is formed, alternating between the prewar and postwar 
stylistics of construction volumes, proportion, and structure. In the city plan of 1935, the building character, the dense street connection to the levee, and the rail line along it are clearly readable. With disappearing of the fine building structure in the urban planning along Spīkeru and Graudu streets (Kaula, Olu, Kuğinieku, Dzirnavu, Putekḷu, Veru, Ķēniņu, Enkuru, Zviedru, Miķeḷa streets), a monotone unwieldy postwar building has appeared instead of it. The mosaic-type fine break up of the historic urban space in the design and facades is in sharp contrast to the exaggerated volumes of the production buildings (the $70 \mathrm{~s}$ of the $20^{\text {th }}$ century, at Spīķeru street 19/24, O. Kalpaka street). Evening out of the different character of the building is successfully launched with the creation of the wedgetype character of the elements of the green outdoor space at the levee. The production buildings made from impersonal reinforced concrete panels, suppression of the facade with a wide dogwood line, the colorfulness of which is read even in the winter are a good example (the 70 s of the $20^{\text {th }}$ century). The place of the connection of Celtnieku street to the waterfront of the canal is enriched by the plantation of a line of linden trees. In turn, the connection expression of the narrow Zviedru street to the waterfront of the canal is decorated by the pine plantation row that in the summer merges with the low plantation belt along the warehouse at Vecā ostmalā 51. In small sections, Fr. Brīvzemnieka street is the makeup of different paving materials - forged cobble, small shape granite stones, clinker patterns, concrete bricks. The pavement structure and color game compositionally create the street "flow into" the canal, so increasing linking of the adjacent historic industrial building with the waterfront (figure 4)

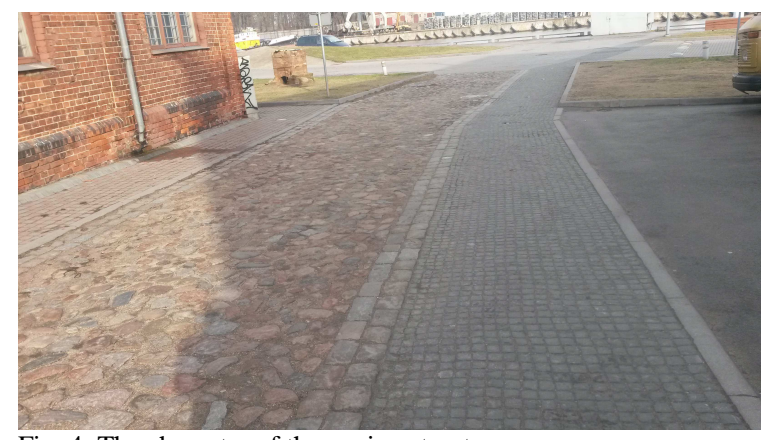

Fig. 4. The character of the paving structure at Fr. Brīvzemnieka iela 7 (photo by authors, 2017.)

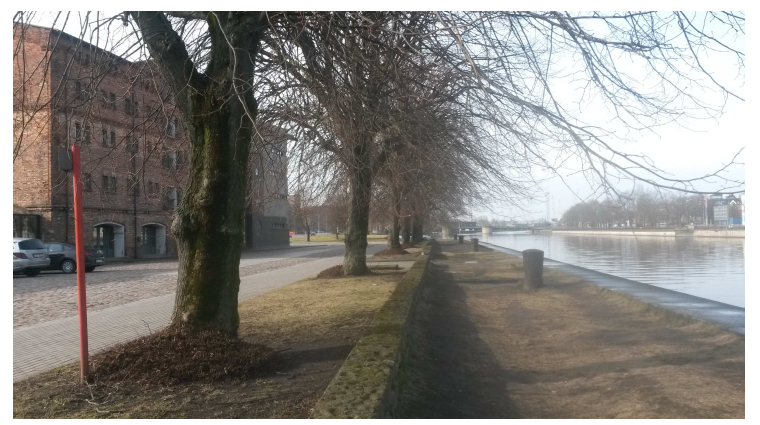

Fig.5. A linden row at Vecā ostmala (photo by authors, 2017.)

Individual islands of the plantation along the waterfront of the canal are formed by the groundcover pines that emotionally powerfully tune with the wild rose plantation group adjacent to the line of vessels along the waterfront of the canal. The rose thorns, the ferocity of the sea wind, the green deck of pines, and the metallic luster of vessels create a strong philosophical site and a sight point at the waterfront. As the culmination in the landscape space of the left bank of the promenade, $150 \mathrm{~m}$ in length there is an inclined plank stay, imitating the ship's gangway. This leads to the Dzintara Concert Hall, built in the brown-yellowish tone. The feeling of the presence of giant sea vessels in the urban space is increased in a compositionally powerful and successfully pictorial language. In the language of form creation, a metaphor is used, imitating the concert hall as an amber vessel stuck ashore between the houses ( figure 6). The powerful comparison made architecturally and artistically in high quality is a good contribution to any urban space.

The verticals of vessels against the horizontal flow of the industrial canal and the horizontal line of the building silhouette create contrastingly strong closing of the western edge of the city's skyline.

The building line of the industrial heritage also continues upstream the canal. Three parallel compositional axes which consist of the industrial building, the street, the linden plantation row, the canal and its coastline are a picturesque and powerful sight point in the urban space (figure 5). Each of these axes creates its own colorful line: the industrial building - the vertical plane of the red bricks, the driveway - the gray-tone horizontal plane, the tree row - an array of the green foliage, the grassy area along the bank and finally - the blue-gray tone of the canal. The above $100 \mathrm{~m}$ long waterfront creates the richest expression in coloring and form creation. The same applies to the tree line at Vecà ostmala 16/18. Here, the waterfront keeps the slope of the historic canal and it has no concrete borders, showing of the historic landscape space shortly before the outlet of the canal from Lake Liepāja. The featured waterfront section $1.5 \mathrm{~km}$ in length is concluded by a vertical dominant - the water tower opposite the railway bridge over the canal. 
The right bank of the canal consists of several picturesque spots. One of them is the intersection of O. Kalpaks and Kaiju streets. At this point in terms of the architectural expression, a powerful building (arch. M. Bertschy) meets with an extensive green area, consisting of the burial area of the Catholic cemetery. Alongside, there locates the other grave area - the Old Liepāja Cemetery, readable from the left bank of the promenade which in the sight lines during the summer time create a picturesque green park feeling adjacent to the waterfront. It is possible to obtain an aesthetically high visual quality if behind the closed burial area along the waterfront of the canal a walking park will be created in the perspective.

The old cemetery - possibly a place where Liepāja started to grow. By creating a walking park/promenade accessible to the general public along the cemetery mound, the view on the panorama of Old Vecliepāja, the old levee with yachts, sailing and fishing boats, openness towards the southern sun would make the site one of the best in the city.

The analysis of the points of sight.

The visually aesthetic quality and variability of the banks of the Trade Canal are readable when taking a walk and in some sight points where particularly stand out the picturesqueness of the longitudinal axis of the canal and the harmony of the elements of the composition. Thanks to the landscape space of the canal, the city's silhouette is brightly marked by the left bank of the canal and the spire of Ann's church in the background.

The expression of the silhouette in the sight point of Tramvaja Bridge consists of two angles of sight:

The downstream of the canal - on the left bank, a developed area with strong accents opens, by means of merging together of the historical and postwar building of the $19^{\text {th }}$ century, with a compositionally balanced walking promenade saturated with artsculpture-small forms of architecture. The light graygreen waves of the waters of the canal and water masses emotionally intensify the feelings. As the dominant, in the sight point, the new concert hall appears rising above the bank-line building and attracting with the contrasting colorfulness of the exterior decoration of the facade. The sight point is characterized by a dense building, wide bank square of the promenade area, the gray water masses of the canal, the changing silhouettes of vessels, greenery. At the sight of the right bank of the canal, expressive red brick warehouse buildings built in the $19^{\text {th }}$ century can be viewed in the compositions with the mound of the Old Graveyard ingrown in large trees. From the side of the bridge, the present function of the current building in the close-up vision is unreadable, both areas are partially or completely closed, their attractiveness should be developed.

The sight point of Tramvaja Bridge to the lakeside upstream the canal allows to watch the flat city's landscape with a smooth, groomed linden plantation, a walking trail with benches, a wide indentation to the building that hides behind a tree line, however at the background it creates a common building belt of the facade, including the buildings of the historical industrial heritage. The sight point is concluded by New Bridge. Watching the left bank of the canal toward the lake, a broad green belt and the street front repeat, which on the whole form a large indentation from the canal where the trees of the waterfront of the canal are reflected in the water. The facilities of the industrial heritage are well readable - the warehouse near the canal, the nearby former liqueur factory buildings, and its area. The former Workers House, also the guard house, and the customs house magnificently stand out in the close-up. In the center position of the sight point between these volumes, the bright volumes of the supermarket and the petrol station are positioned, revealing the current events and the value of life of the modern townspeople. In the central part of the city, a certain disproportion of accents can be observed.

Secondly, the sight points at Jaunais Bridge and the former railway bridge should be noted as being expressive and active where the gently sloping banks of the canal with a smooth willow row, the Latvian Gas building complex in the red brick architecture fit in the viewing landscape, the expressiveness of which is sharpened by the modern mirror facades of the adjacent buildings, reflecting the historical building. The water tower built in the $19^{\text {th }}$ century rises as a dominant surrounded by Ganību and Ezermalas streets on the right bank of the canal which visually successfully links the memory story of the industrial heritage of the two banks.

One of the most expressive sight points - the Liepāja old burial mound which offers the city panorama with a blue-green line of waters of the Trade Canal at the forefront, the promenade in the middle and a story of a rich architectural heritage and creativeness behind it. The area of the cemetery is partially closed, the walking trail around it should be developed to make the sight points available towards the south and towards the urban landscape at the Trade Canal.

The sight points from the factory areas of O. Kalpaka street towards the left bank of the canal and vice versa are inaccessible to the residents of the city and tourists but they are expressive. The facilities of the industrial heritage designed by P. M. Bertschy in this place should be developed, giving new functions, creating valuable points of sight towards them.

The third important aspect is the rhythm of the seasons and its impact on the changes of the picturesqueness of the landscape space.

The visual attractiveness of the Liepāja canal, thanks to the green or colorful foliage is revealed fully during the ascetic autumn and winter time when 
the trees create clear graphic images and the urban structure is readable up to minute details (figure 7).

During the winter period, the tree graphics, snow white, the frozen water plane of the canal create a calm background for the expressive - especially characteristic to Liepāja - red brick buildings of the industrial heritage.

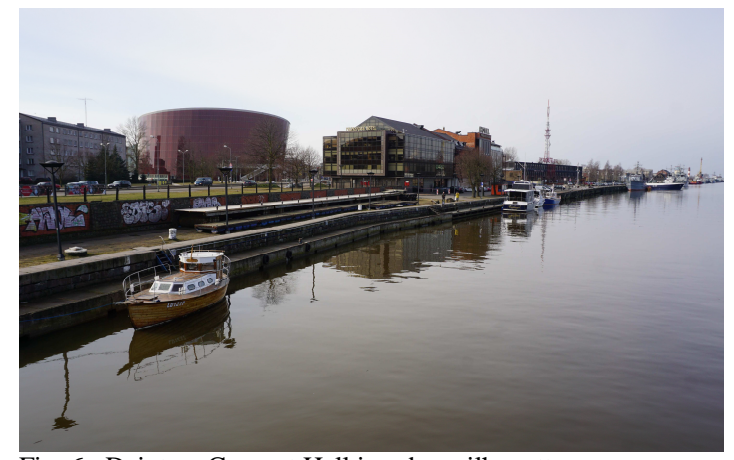

Fig. 6. Dzintara Concert Hall in urban silhouette.

(photo by authors, 2017.)

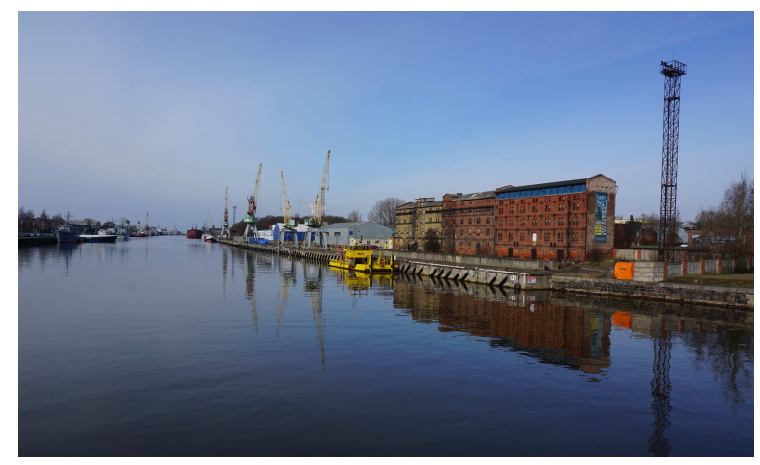

Fig.7. The harmony of the bank building and the

Vessels silhouette (photo by authors, 2017.)

\section{CONCLUSION}

The transformation of the landscape space on the banks of the Trade Canal has been affected by a number of rising up and down periods of history - the successful activities of P. Bertschy (1871 - 1902), the devastating years of the wars (1914-1920, 19411945), the years of independence (1918-1940), the period of socialism (1945-1990), the contemporary view on the matters of the cultural heritage. Each of the periods brings along the change of the structure, the compositional structure, or the purpose. By studying separately each of these criteria for the waterfront of the canal, we can conclude that : 1)The structure of the urban space under the study and the building scale as the most sensitive elements of the space design have created a vivid reflection of its time in each of the above periods; 2)The sharp change of the compositional structure of the levee in the race of over one hundred years characterizes each period of the economic and political situation;3) The canal has not changed its functional significance since the time of its construction. It is not changed into a site of an intensive industrial and military significance or a narrow tourism-owned site. The only thing that has changed is the importance of the waterfront of the canal. From a dense fish stall, it has transformed into an elegant space of historical reference with a readable urban identity. 4)The green belts of the waterfront are fragmented and they do not have a harmonious context with the architectural shape of the building on the waterfront of the canal. The evaluation of the landscape space for the waterfront of the canal in Liepāja is one of the most important parts of the city planning. The winding of the left bank of the canal is marked by an expressive silhouette line of the city which is readable in the long distance points of sight. By contrast, the silhouette of the right bank is readable in the near sight lines. The changing point of sight lengths and angles make up a multi-faceted urban perception. This is an important contribution to the city's architectural and spatial form.

\section{REFERENCES}

1. Anteniške, A. (2002). Industrial heritage of Riga in the European context. "Industrial heritage in the modern urban environment", International conference Riga.Riga city council, 2003, 26-32 p. ISBN 9984-31-288-7

2. Bredin, G.(2002). From Paper mill to concert hall industrial and cultural heritage in Norrkoping. "Industrial heritage in the modern urban environment", International conference Riga. Riga city council, 2003, 36-39 p. ISBN 9984-31-288-7

3. Briṇkis,J., Buka,O. (2008). Reǵionālā attīstība un prognostika pilsētplānošanas kontekstā. 195 p. ISBN 978-9984-32-255-1

4. Krastiņš,J. (2015). Liepāja. Jūgendstila arhitektūra.376 p.ISBN 978-9934-14-464-6

5. Lastovecka, L. (2002). Industrial heritage in the electric power industry. "Industrial heritage in the modern urban environment", International conference Riga. Riga city council, 2003, 65-69 p. ISBN 9984-31-288-7

6. Sivula, A. (2002.) Pori cotton factory as a case of industrial heritage in modern urban environment. "Industrial heritage in the modern urban environment", International conference Riga. Riga city council, 2003, 44-50 p. ISBN 9984-31-288-7

7. Stradiņš, J. (2002). Industrial heritage of Riga and the history of sciences. "Industrial heritage in the modern urban environment", International conference Riga. Riga city council, 2003, 7-13 p. ISBN 9984-31-288-7

8. Wennerholm, A. (2002). Industrial heritage as a force in the democratic society."Industrial heritage in the modern urban environment", International conference Riga. Riga city council, 2003, 19-20 p. ISBN 9984-31-288-7

9. Zbiegieni, A.(2002). The current problems of renovation and integration the industrial heritage sites in the modern urban environment in Warschaw agglomeration. International conference Riga. "Industrial heritage in the modern urban environment", International conference Riga. Riga city council, 2003, 40-43 p. ISBN 9984-31-288-7 